\title{
Analysis of Risk Assessment on Integrated Information System using COBIT 5 Framework
}

\author{
Citra Dika Saputra \\ Department of Information System \\ Universitas Ahmad Dahlan \\ Yogyakarta of Indonesia
}

\author{
Imam Riadi \\ Department of Information System \\ Universitas Ahmad Dahlan \\ Yogyakarta of Indonesia
}

\begin{abstract}
The Integrated Service Management Information System is dedicated to providing the best service in terms of population administration and licensing services to the community. The Integrated Service SIM can be accessed through the Jogja Smart Service (JSS) application or http://jss.jogjakota.go.id. Integrated Services allow for risks that can interfere with information assets and organizational goals. This study uses the COBIT 5 framework which aims to analyze risk assessment so that organizations can choose a mitigation approach to risks that may occur and provide recommendations. The risk management assessment in this study uses the COBIT 5 process domain framework EDM03 (Ensure Risk Optimization) and APO12 (Risk Management). This study aims to determine the level of IT risk management capability using the COBIT 5 Process Assessment Model (PAM) methodology which consists of the Initiation, Planning the Assessment, Briefing, Data Collection, Data Validation, Process Attribute Level and Reporting the Result stages. Calculation of the questionnaire using the Likert Scale method. The result of the research is that the Capability level value in the EDM03 domain is at level 2 with a capability value of 1.63 , at this level the Integrated Service SIM has implemented the Managed Process. EDM03 has a Gap value of 1 level, this is the basis for making recommendations. While in the APO12 domain it is at level 1 with a capability value of 1.42 at this level Integrated Service SIM has implemented Performed Process. APO12 has a Gap value of 1 level, this is the basis for making recommendations. This research was carried out well in accordance with the expected research objectives.
\end{abstract}

\section{Keywords}

Risk Management, Capability Level, Gap, RACI Chart, Skala Likert

\section{INTRODUCTION}

Currently the development of IT is growing rapidly, thus making many companies or related agencies apply IT in assisting business processes in order to maintain the smooth business operations of a company or an agency. With the development of IT, a company or agency can guarantee a quality information presented and the company or agency can make decisions based on information systems.

The development of Information Technology (IT) is also implemented by the Kotagede District Office which is located on NYI WIJIADISONO Street No. 39, Prenggan, Kotagede, Yogyakarta City, Special Region of Yogyakarta 55172. One of the services implemented by Kotagede District Yogyakarta is in the application of Village and District Services. . Orations for Kelurahan and Kecamatan Services can be accessed online through the Jogja Smart Service (JSS) application. The Village and District Service Information System can help the community and make it easier for the community. The scope of service delivery in the electronicbased village and sub-district includes population administration and licensing services.

Risk assessment analysis has several frameworks or methods that can be used to measure risk assessment services in an agency including COBIT, OCTAVE, ITIL, NIST and several other frameworks or methods. In this study the author will use the COBIT 5 framework or method.

\section{LITERATURE STUDIES}

\subsection{Understanding Analysis}

According to (Komaruddin, 2001) that the notion of analysis is a thinking activity to describe a whole into components so that they can recognize the signs of the components, their relationship to each other and their respective functions in an integrated whole. [12]

\subsection{Understanding Risk}

Risk is the possibility of deviations from expectations that can cause losses. Risk can come at any time, so that risk does not hinder activities, then the risk must be managed properly (Ali, Masyhud, 2006). [2]

\subsection{Information Technology Risk Management}

According to (Stewart, Chapple, \& Gibson, 2015) risk management is a detailed process to identify factors that can damage or disclose data, evaluate these factors in terms of data value and the cost of countermeasures, and implement motivated solutions for risk mitigation or reduction. . So risk management is a process to identify and analyze the risks that exist in an organization or company. [19]

\subsection{COBIT 5}

COBIT 5 (Control Objective for Information and Related Technology) is a set of guidelines and documentation that serves to assist stakeholders or users in connecting between the business control model and the IT control model. COBIT 5 is an amalgamation of the latest thinking in corporate governance and management techniques. COBIT 5 is deeply able to assist companies in creating optimal value from IT, namely between realizing benefits and optimizing risk levels with resource use. COBIT was developed to implement IT Governance of Enterprise. The latest version released by the 
IT Governance Institute is known as COBIT 5. COBIT 5 was formed by integrating the Risk IT framework, VAL IT 2.0 and COBIT 4.1. In addition, COBIT 5 also adjusts the existing best practices such as ITIL V3, TOGAF and relevant standards from ISO.

According to ISACA (2012) there are seven stages in the COBIT 5 implementation cycle, namely: [11]

1. Initiate Program, is the stage to identify company drivers

2. Define Problems and Opportunities, is the stage to assess the capability level to find out the current condition of the organization and find its shortcomings.

3. Define Road Map, is the stage for setting targets and analyzing gaps to increase improvement efforts and identify potential solutions.

4. Plan Programme, is the stage to plan solutions that are considered appropriate to be implemented.

5. Execute Plan, is the stage to implement the planned solution and monitor business alignment.

6. Realise Benefits, is a transitional stage on an ongoing basis by implementing improved governance or management practices into business processes and monitoring progress by mapping them on a matrix based on performance and benefits to be obtained

7. Review Effectiveness, is a stage to evaluate the success that has been achieved, then identify all improvement needs on a regular basis

In the 2012 ISACA journal, COBIT 5 (Control Objectives for Information and Related Technology) explained that in general it has 5 basic principles and the following are 5 basic principles in Cobit 5: [10]

1. The first principle (Meeting Stakeholder Needs) is to meet the needs (stakeholders) to maintain balance and optimize risk because each company has a different vision and mission.

2. The second principle is (Covering the Enterprise end-toend), which is covering the End-to-End enterprise considering all IT governance and management enablers for the company or optimizing IT governance for each company.

3. The third principle (Applying a single, Integrated Framework) is related standards that usually provide guidance for some IT activities.

4. The fourth principle (Enabling a Holistic Approach) is that effective and efficient corporate IT governance and management requires a comprehensive approach, which considers interacting components. COBIT 5 defines a set of enablers to support the comprehensive implementation of corporate IT system governance and management.

5. The fifth principle (Separating Governance from Management) is to provide a clear separation between management and governance. They cover different activities, require different organizational structures and serve different purposes.

In addition to the 5 principles described above, there are 7 enablers contained in COBIT 5, here are the explanations for these 7 supporters. The description 7 enablers in COBIT 5 can be seen in Figure 1 [10]

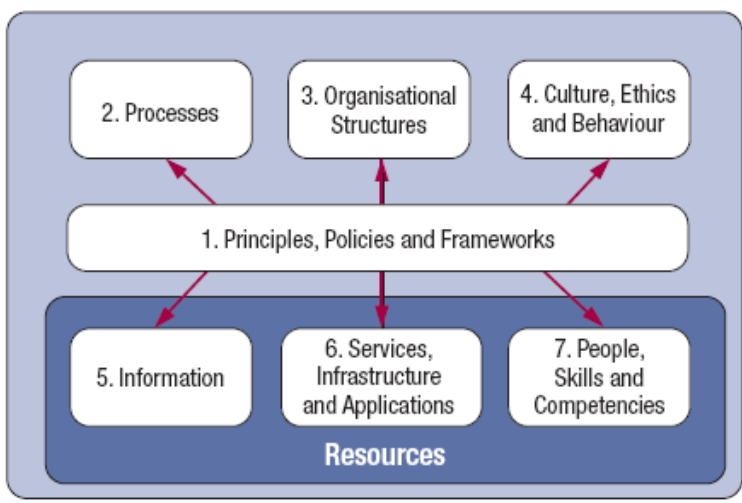

Figure 1.7 enablers in COBIT 5

1. Policy principles and frameworks are the first enablers of COBIT 5, these enablers function to formulate needs and behaviors (stakeholders) into practical guidelines that will be used in company operations in the IT sector.

2. The process as an enabler has a role to provide details about a series of activities and practical activities carried out to achieve the goals of the company.

3. Organizational structure is the key in decision making in the organization. The decisions made must also meet the needs and objectives of all (stakeholders). So that the entity is responsible for the decisions and policies made by the company.

4. Every company has its own culture, ethics and habits, these habits can occur due to many factors and can also be personal or organizational. Some values and company goals can only be achieved with good corporate habits, therefore a standard is needed to provide an assessment of a culture, custom and ethics.

5. Information is a very important factor for business activities within a company because information is a requirement for making movements within the company such as making decisions and solving problems.

6. Infrastructure and applications including infrastructure, technology and applications that provide services are objects and objects become drivers in COBIT 5. These objects provide services to technology and information processes for companies.

7. Skills and competencies relate to people and are needed to carry out all activities successfully and make appropriate decisions and take corrective actions.

According to ISACA (2012), COBIT 5 has two processes that discuss Information Technology (IT) risk management, namely EDM03 and APO12. [11]

1. EDM03 (Ensure Risk Optimization) Aims to ensure the level of risk and acceptable tolerance levels for the company are well understood, articulated and communicated, as well as ensuring whether IT-related risks have been identified and managed properly. The EDM03 process consists of EDM03.01 (Evaluate Risk Management), DM03.02 (Direct Risk Management) and EDM03.03 (Monitor Risk Management).

2. APO12 (Manage Risk) Aims to identify, assess and reduce risks related to IT so as not to exceed the tolerance limits that have been determined by the organization. And integrate IT risk management with 
enterprise risk management (ERM). This process consists of APO12.01 (Collect Data), APO12.02 (Analyse Risk), APO12.03 (Maintain A Risk Profile), APO12.04 (Articulate Risk), APO12.05 (Define a Risk Management Action Portfolio) and APO12.06 (Respond to Risk).

\subsection{Capability Level}

The measurement criteria are based on the measurement points that exist in the COBIT 5 self-assessment template, the rating scale that will be used in the measurement at each level which will later be used to meet the value at each point as shown in the following table 1: [10]

Table 1. Rekapitulasi Hasil Capability Level

\begin{tabular}{|c|c|c|}
\hline Kode & Keterangan & Range \\
\hline N & Not achieved & $0-15 \%$ \\
\hline P & Partially achieved & $>15-50 \%$ \\
\hline L & Largely achieved & $>50-85 \%$ \\
\hline F & Fully achieved & $>85-100 \%$ \\
\hline
\end{tabular}

1. $\quad \mathrm{N}$ (Not achieved)

In this category there is no or little evidence of the achievement of the process attributes. The range of values achieved in this category ranges from $0-15 \%$.

2. $\quad \mathrm{P}$ (Partially achieved)

In this category, there is some evidence regarding the approach, and several attribute achievements for the process. The range of scores achieved in this category ranges from $15-50 \%$.

3. L (Largely achieved)

In this category there is evidence of a systematic approach, and significant achievements in the process, although there may still be insignificant weaknesses. The range of scores achieved in this category ranges from $50-85 \%$.

4. F (Fully Ahieved)

In this category there is evidence of a systematic and complete approach, and full achievement of the attributes of the process. There are no weaknesses related to the attributes of the process. The range of scores achieved in this category ranges from $85-100 \%$.

\subsection{Likert Scale Calculation Method}

This study uses a measurement scale with a Likert scale. According to Azwar (2011), the Likert Scale is an attitude statement scaling method that uses the response distribution as the basis for determining the scale value. The scale is named after its creator Rensis Likert, who published a report describing its use.

In determining the value and capability level of the EDM03 and APO12 processes, the researcher uses the Likert scale calculation method used by Krisdanto Suhendro in his book entitled Implementation of IT Governance.

Calculating the Recapitulation of Answers to the Questionnaire

$$
C=\frac{\mathbf{H}}{\mathrm{JR}} \times 100 \%
$$

Description:

C: Recapitulation of answers to the Capability Level questionnaire (in the form of percentages for each answer choice $\mathrm{a}, \mathrm{b}, \mathrm{c}, \mathrm{d}$, e or $\mathrm{f}$ in each activity).

$\mathrm{H}$ : The number of answers to the Capability Level questionnaire for each answer choice $\mathrm{a}, \mathrm{b}, \mathrm{c}, \mathrm{d}$, e or $\mathrm{f}$ in each activity.

JR: Number of Respondents/Resources.

Calculating Capability Scores and Levels

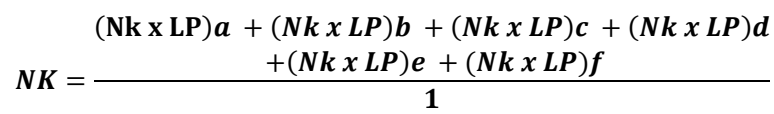

Description:

NK: Capability value in IT process

LP: Level percentage (Percentage level in each distribution ofquestionnaire answers capability level).

Nk: The capability value listed in the answer mapping table, value and capability level.

\section{METHODOLOGY}

In this study, the author will use quantitative research methods. The reason in this study using quantitative methods is because in data processing this research produces values in the form of numbers and calculation analysis using statistics. In this study the author will divide several steps in the process of data collection. The following are the steps in the data collection process: [17]

1. Observation is a complex data collection method because it involves various factors in its implementation. In this study, observations were made by studying or understanding the Kelurahan and Kecamatan Service Information System at the Kotagede Subdistrict Office, Yogyakarta.

2. Literature study is a method of collecting data that is not addressed directly to the research subject. Collecting data and information from sources related to the research topic.

3. Interview is a data collection technique that is carried out through face-to-face and direct questions and answers between researchers and resource persons. This interview was conducted with the aim of obtaining accurate information from trusted sources.

4. Questionnaire is a method of collecting data by giving a set of questions or written statements to respondents to answer

\subsection{Data Analysis Method}

This research will use primary data and secondary data. Primary data were obtained through interviews, observations and questionnaires distributed to the Kotagede District Office, Yogyakarta. While secondary data is obtained from the internet, from institutions or agencies and also obtained from trusted articles to assist in the process of collecting data. The collection of primary and secondary data is very important to 
be carried out and collected to make research materials and these stages must be carried out correctly so that there are no errors in data collection that will be used as material for further research. Then the data will be analyzed related to the risk assessment of the SIM Jogja Smart Service.

\subsection{Data Analysis Stages}

The data analysis method used in identifying the capability level to be carried out, to find gaps and determine appropriate recommendations, researchers used Assessment Process Activities based on the COBIT 5 framework which consists of seven process stages and seven stages of this process must be carried out correctly and thoroughly. Here are the seven stages: [10]

1. Initiation this stage describes the drivers in the organization. Identify current change drivers and change needs at the executive management level. The goal is to gain an understanding of the current organization.

2. Planning the Assessment The second stage is to carry out an assessment plan that aims to obtain the results of the evaluation of the capability level assessment. This stage carries out an assessment plan that aims to obtain the data needed for EDM03 (Ensure Risk Optimization) and APO12 (Manage Risk).

3. Briefing In this third stage, the researcher provides direction to the respondents in the RACI diagram so that they understand the inputs, processes and outputs in the organizational unit and explain the schedule.

4. Data Collection The fourth stage is collecting data from the findings contained in the agency/organization which aims to obtain evidence of evaluation assessment on process activities that have been carried out.

5. Data Validation The fifth stage is data validation which aims to determine the results of the questionnaire calculations in order to obtain an evaluation of the capability level assessment.

6. Process Attribute Level The sixth stage is the process of assigning a level to the attributes that exist in each indicator, which aims to show the capability level results from the results of the questionnaire calculations in the previous stages and perform a gap analysis at the next stage.

7. Reporting the Result The seventh stage At this stage the researcher reports the results of the evaluation that has been carried out by providing a report on the results of risk identification and gap analysis which can be used as a company to achieve the expected level.

\subsection{Research stage}

Below are the research stages shown in Figure 2.

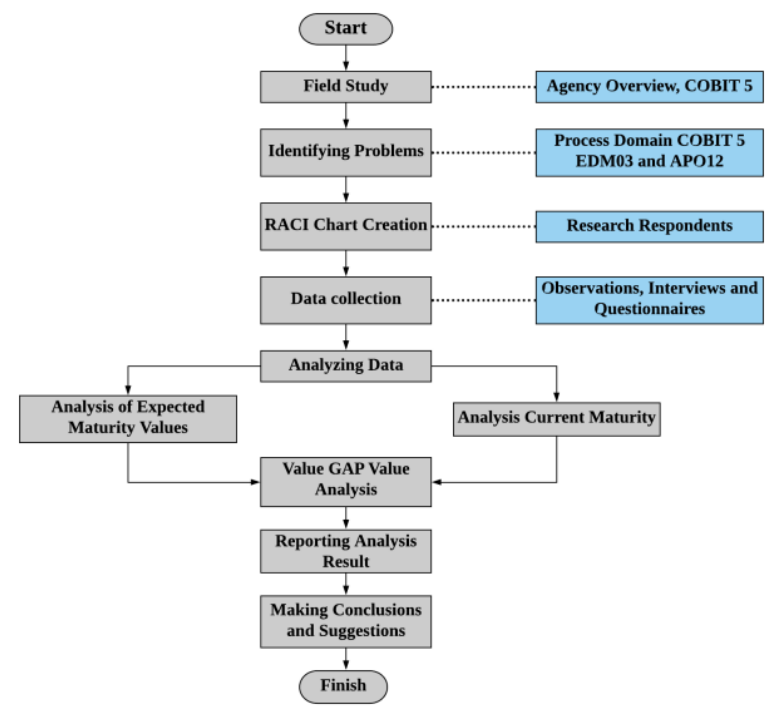

Figure 2.Research stage

1. The first stage of research begins with a literature study. Literature study was conducted in order to get an overview of the relevant agencies that became the object of the research and to find the COBIT 5 theory that supports this research. Literature studies are obtained through theses, journals and books that support this research.

2. The second stage is identifying the problem. After the first task has been completed, it will be followed by the stage of identifying the problem that serves to get the problem to be solved by the author. Then the author will identify problems using the COBIT 5 process by determining the process subdomains, namely APO12 and EDM03 to determine the RACI Chart.

3. The third stage is making the RACI Chart obtained from the respondents in the study. The RACI Chart will be used for decision making and assist in identifying the roles and responsibilities of each respondent.

4. The fourth stage is data collection. After the writer defines the problem, the next step is to collect data in order to solve the problem by conducting observations, interviews, and questionnaires.

5. The fifth stage is analyzing the data. After collecting the required data from observations, interviews, and questionnaires. The next step is to analyze the data by analyzing the expected maturity value and also by analyzing the current maturity value.

6. The sixth stage is the analysis of the GAP value. The GAP value is the difference value obtained after the author performs the calculation of the expected maturity value analysis with the current maturity value analysis.

7. The last stage is making conclusions from all activities carried out in research and suggestions for further research.

\subsection{Risk Assessment Method}

Risk Assessment Method used in this study uses the COBIT 5 framework. Cobit 5 is used because it is in accordance with 
the risk assessment process to be carried out. This risk assessment focuses on the Jogja Smart Service Integrated Service SIM which is located in the Kotagede sub-district of Yogyakarta as a place of research. This research was conducted by focusing on 2 domains, namely EDM03 (Ensure Risk Optimization) and APO12 (manage risk). The assessment process in the assessment process in EDM03 (Ensure Risk Optimization) age. The assessment process in the assessment process in EDM03 (Ensure Risk Optimization) ensures risk optimization, namely to ensure that agency risks can be understood, articulated and communicated against agency values related to the use of IT that are identified and managed properly.

Meanwhile, APO12 (manage risk) focuses more on identifying, assessing, and reducing IT-related risks within the tolerance level determined by agency management. The results of this study are expected to provide recommendations and mitigation measures to improve quality control to reduce the risks that may occur. The following are the stages of the assessment carried out during the research process.

\section{RESULTS AND DISCUSSION}

\subsection{Analysis Results Determination of Capability Levels The}

The following is the determination of the EDM03 capability level based on the results of the calculation of the capability value contained in each sub-process. The results of each process in EDM03 can be seen in the table by identifying the capability value and capability level. Then look at the current condition (as is) and the expected condition (to be). The following explanation can be seen in table 2 .

Table 2. Determination of the capability level of EDM03

\begin{tabular}{|c|c|c|c|c|}
\hline \multirow{2}{*}{ Sub-Domain } & \multicolumn{2}{|c|}{ Nilai Kapabilitas } & \multicolumn{2}{c|}{ Capability Level } \\
\cline { 2 - 5 } & As is & To be & As is & To be \\
\hline EDM03.01 & 1.54 & 2.54 & $\mathbf{2}$ & $\mathbf{3}$ \\
\hline EDM03.02 & 1.79 & 2.71 & $\mathbf{2}$ & $\mathbf{3}$ \\
\hline EDM03.03 & 1.56 & 2.56 & $\mathbf{2}$ & $\mathbf{3}$ \\
\hline Rata-Rata & 1.63 & 2.60 & $\mathbf{2}$ & $\mathbf{3}$ \\
\hline
\end{tabular}

Based on the table 2 above, it is known that the EDM03.01 process capability level is currently at level 2 with a capability value of 1.54, in the EDM03.02 process the capability level is currently at level 2 with a capability value of 1.79 , in the EDM03.03 process capability level. currently at level 2 with a capability value of 1.56 . From From the three sub-processes contained in COBIT 5, from the results of research on the Integrated Service SIM Jogjja Smart Service, it is known that the capability value for the EDM03 process is 1.63 .

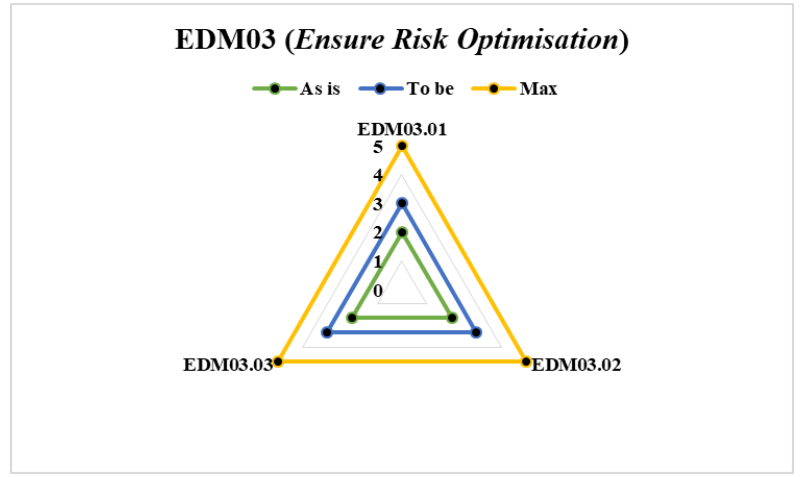

Figure 3. Graph of the EDM03 process

Based on the figure 3 graph above, it is known that the current condition of the EDM03 (Ensure Risk Optimization) process is at level 2 with a capability value of 1.63 , at this level the Integrated Service SIM has implemented a Managed Process while the expected conditions (to be) is at level 3 with a capability value of 2.60 which at this stage has been implemented Established Process.

The following is the determination of the APO12 capability level based on the results of the calculation of the capability value contained in each sub-process.Determination of APO12 capability level can be seen in table 3 .

Table 3. Determination of APO12 capability level

\begin{tabular}{|c|c|c|c|c|}
\hline \multirow{2}{*}{ Sub-Domain } & \multicolumn{2}{|c|}{ Nilai Kapabilitas } & \multicolumn{2}{c|}{ Capability Level } \\
\cline { 2 - 5 } & As is & To be & As is & To be \\
\hline APO12.01 & 1.64 & 2.78 & $\mathbf{2}$ & $\mathbf{3}$ \\
\hline APO12.02 & 1.21 & 2.21 & $\mathbf{1}$ & $\mathbf{2}$ \\
\hline APO12.03 & 1.24 & 2.24 & $\mathbf{1}$ & $\mathbf{2}$ \\
\hline APO12.04 & 1.55 & 2.55 & $\mathbf{2}$ & $\mathbf{3}$ \\
\hline APO12.05 & 1.33 & 2.33 & $\mathbf{1}$ & $\mathbf{2}$ \\
\hline APO12.06 & 1.56 & 2.56 & $\mathbf{2}$ & $\mathbf{3}$ \\
\hline Rata-Rata & 1.42 & 2.44 & 1.33 & 2.5 \\
\hline
\end{tabular}

Based on the table 3 above, it is known that in sub -process APO12.01 capability level is currently at level 2 with a capability value of 1.64, in sub -process APO12.02 capability level is currently at level 1 with a capability value of 1.21 , in sub -process APO12 .03 capability level is currently at level 1 with a capability value of 1.24 , in sub -process APO12.04 capability level is currently at level 2 with a capability value of 1.55, in sub -process APO12.05 capability level is currently at level 1 with a capability value of 1.33 , in the sub -process APO12.06 capability level is currently at level 2 with a capability value of 2.56 . From the six sub-processes contained in COBIT 5, from the results of research on the Integrated Service SIM Jogjja Smart Service, it is known that the capability value for the APO12 process is 1.42 . 


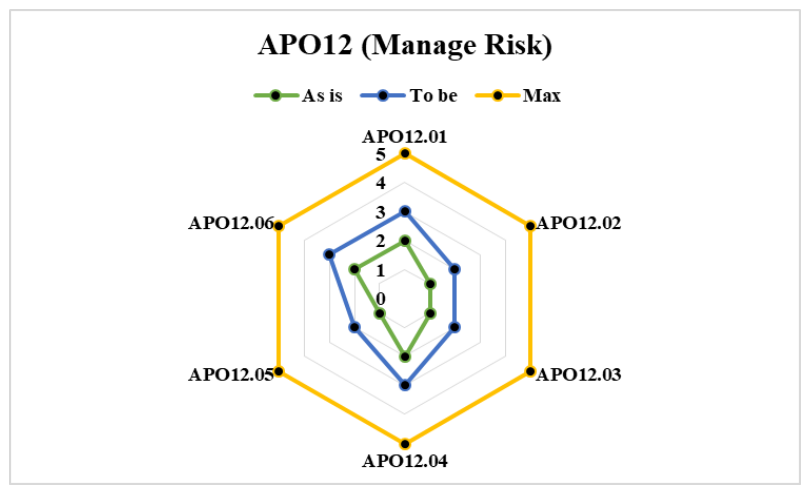

Figure 4.Graph of the APO12 process

Based on the figure 4 graph above, it is known that the current condition of the APO12 process (Manage Risk) is at level 1 with a capability value of 1.42 , at this level the Integrated Services SIM division has implemented the Performed Process while the expected conditions (to be) is at level 2 with a capability value of 2.44 which at this stage has implemented Managed Process.

\section{Capability Level and Gap}

Based on the data from the questionnaire that has been validated with interview data and observations of supporting evidence or documents. The result is the capability level of Integrated Service SIM in Kotagede District, Yogyakarta. The current Capability Level (as is) in the EDM03 Ensure Risk Optimization process is at level 2 (Managed Process) with a capability value of 1.63 while the expected capability level (to be) is at level 3 (Established Process) with a capability value of 2.60. Meanwhile, the current Capability Level (as is) in the APO12 Manage Risk process is at level 1 (Performed Process) with a capability value of 1.42 while the expected capability level (to be) is at level 2 (Managed Process) with a capability value of 2. ,44.Capability Level Results Recapitulation can be seen in table 4 .

Table 4. Capability Level Results Recapitulation

\begin{tabular}{|c|c|c|c|}
\hline Nama Proses & As is & To be & Gap \\
\hline $\begin{array}{c}\text { EDM03 (Ensure Risk } \\
\text { Optimisation) }\end{array}$ & 2 & 3 & 1 \\
\hline APO12 (Manage Risk) & 1 & 2 & 1 \\
\hline
\end{tabular}

\subsection{Capability Level Analysis Results}

The following are the results of the overall capability level assessment of the processes that have been assessed:

1. The current Capability Level (as is) in the EDM03 Ensure Risk Optimization process is at level 2 (Managed Process) with a capability value of 1.63 while for The expected capability level (to be) is at level 3 (Established Process) with a capability value of 2.60 .

2. The current capability level (as is) in the APO12 Manage Risk process is at level 1 (Performed Process) with a capability value of 1.42 while the expected capability level (to be) is at level 2 (Managed Process) with a capability value 2.44 .

Based on the data from the assessment results in each process, the authors then provide recommendations as suggestions for improvement in order to achieve the expected conditions for each process in accordance with COBIT 5 standards.

\subsection{EDM03 Process Gaps and Recommendations}

The value obtained in the capability level assessment is at level 2 with the expected conditions at level 3, to achieve the capability level, these gaps and recommendations are obtained from the results of fulfilling the process that has been described at the Process Attribute Level stage so that the recommendations given are in accordance with the needs. current organization. The results of the recapitulation are as follows. Capability level in the EDM03 process can be seen in table 5 .

Table 5. Capability level in the EDM03 process

\begin{tabular}{|c|c|c|c|c|c|c|c|c|c|c|}
\hline \multirow{2}{*}{ Process Name } & \multicolumn{10}{|c|}{ Process Capalibility Level } \\
\hline & 0 & 1 & & & & & & & & 5 \\
\hline \multirow{3}{*}{ EDM03 } & & \multirow{3}{*}{ F $100 \%$} & \multicolumn{2}{|c|}{$L 83,33 \%$} & \multicolumn{2}{|c|}{ Desired Level } & & & & \\
\hline & & & 2.1 & 2.2 & 3.1 & 3.2 & 4.1 & 4.2 & 5.1 & 5.2 \\
\hline & & & L $66,67 \%$ & F $100 \%$ & & & & & & \\
\hline \multicolumn{7}{|c|}{ Descriptions: N(Not achieved 0-15\%)P(Partially achieved $15-50 \%)$} & & & & \\
\hline \multicolumn{5}{|c|}{ L(Largely achieved $50-85 \%$ )F(Fully Ahieved $85-100 \%$ ) } & & & & & & \\
\hline
\end{tabular}

Based on the table 5 above, it is known that the capability indicator at level 1 has reached $100 \%$ in thecategory Fully Achieved, so that further assessment is carried out at the following level. The capability indicator at level 2 has 2 points that must be met, namely Performance Management and Work Product Management , both of which have reached $66.67 \%$ and $100 \%$. So thevalue capability level at level 2 is still included in thecategory Largely Achieved with a percentage of $83.33 \%$. Before focusing on achieving at the expected level. The SIM for Integrated Services in Kotagede District is recommended to fulfill the gaps in the previous levels. The following are the recommendations given by the researchers in accordance with the findings obtained at the stage of fulfilling the capability indicators. Gaps and Recommendations EDM03 can be seen in table 6.

Table 6. Gaps and Recommendations EDM03

\begin{tabular}{|l|l|}
\hline \multicolumn{2}{|c|}{ EDM03 Ensure Risk Optimisation } \\
\hline \multicolumn{1}{|c|}{ Gaps } & \multicolumn{1}{c|}{ Rekomendasi } \\
\hline $\begin{array}{l}\text { There is no action to adjust } \\
\text { the performance of therisk } \\
\text { optimization process }\end{array}$ & $\begin{array}{l}\text { SIM for the Integrated } \\
\text { Services of Kotagede District, } \\
\text { it is recommended to make a } \\
\text { report to assess the } \\
\text { performance related to the } \\
\text { optimization of risks that exist } \\
\text { in the services used. }\end{array}$ \\
\hline $\begin{array}{l}\text { The absence of } \\
\text { identification related to the } \\
\text { responsibility for the risk } \\
\text { optimization process for the }\end{array}$ & $\begin{array}{l}\text { SIM Integrated Service SIM } \\
\text { in Kotagede District, it is } \\
\text { recommended to make a risk } \\
\text { profile document in } \\
\text { accordance with the RACI } \\
\text { Chart in order to handle the } \\
\text { existing risks, who is } \\
\text { responsible and has the } \\
\text { authority in this process. }\end{array}$ \\
\hline
\end{tabular}

Based on the table 6 above, it is known that there are 2 gaps that must be met by the Integrated Service SIM in Kotagede 
District in order to meet the requirements for level 3 in the EDM03 process.

\subsection{APO12 Process Gaps and Recommendations}

The value obtained in theassessment capability level is at level 1 with the expected conditions at level 2, to achieve this capability level, these gaps and recommendations are obtained from the results of the fulfillment of the process that has been described at thestage Process Attribute Level so that the recommendations given are in accordance with the needs. current organization. The results of the recapitulation are as follows. Capability level in the APO12 process can be seen in table 7.

Table 7. Capability level in the APO12 process

\begin{tabular}{|c|c|c|c|c|c|c|c|c|c|c|}
\hline \multirow{2}{*}{ Process Name } & \multicolumn{10}{|c|}{ Process Capalibility Level } \\
\hline & 0 & 1 & & & \multicolumn{2}{|c|}{3} & \multicolumn{2}{|c|}{4} & \multicolumn{2}{|c|}{5} \\
\hline \multirow[b]{2}{*}{ APO12 } & \multirow{2}{*}{\multicolumn{2}{|c|}{ F $76,67 \%$}} & \multicolumn{2}{|c|}{ Desired Level } & & & & & & \\
\hline & & & 2.1 & 2.2 & 3.1 & 3.2 & 4.1 & 4.2 & 5.1 & 5.2 \\
\hline \multicolumn{7}{|c|}{ Descriptions: N(Not achieved 0-15\%)P(Partially achieved 15-50\%) } & & & & \\
\hline \multicolumn{5}{|c|}{ L(Largely achieved 50-85\%)F(Fully Ahieved $85-100 \%$ ) } & & & & & & \\
\hline
\end{tabular}

Based on the table 7 above, it is known that the capability indicator at level 1 has only reached $76.67 \%$ so that it is in thecategory Largely Achieved, but there are still several Work Products that must be met so that the assessment at level 1 reaches $100 \%$. Before focusing on achieving at the expected level. The SIM for Integrated Services in Kotagede District is recommended to fulfill the gaps in the previous levels. The following are recommendations given by researchers in accordance with the findings obtained at the stage of fulfilling capability indicators. Gaps and Recommendations APO12 can be seen table 8 .

Table 8. Gaps and Recommendations APO12

\begin{tabular}{|l|l|}
\hline \multicolumn{2}{|c|}{ APO12 Manage Risk } \\
\hline \multicolumn{1}{|c|}{ Gaps } & \multicolumn{1}{c|}{ Rekomendasi } \\
\hline $\begin{array}{l}\text { There is no document that } \\
\text { explains the scope } \\
\text { ofanalysis. Especially for } \\
\text { the IT scope. }\end{array}$ & $\begin{array}{l}\text { The SIM for Integrated } \\
\text { Services in Kotagede District } \\
\text { is recommended to determine } \\
\text { the scope of the risk analysis } \\
\text { effort. Which contains the } \\
\text { boundaries of the unit / } \\
\text { agency about what activities } \\
\text { and strategies are. Who owns } \\
\text { the risk and its extent. It is } \\
\text { recommended to make a risk } \\
\text { analysis with the scope of the } \\
\text { Integrated Service SIM in } \\
\text { Kotagede District. }\end{array}$ \\
\hline $\begin{array}{l}\text { There is no assessment } \\
\text { result by a third party. }\end{array}$ & $\begin{array}{l}\text { It is recommended that the } \\
\text { Kotagede District Integrated } \\
\text { Service SIM cooperate with } \\
\text { third parties in conducting a } \\
\text { risk assessment to complete } \\
\text { the internal audit. Obtain } \\
\text { validity from certified parties. }\end{array}$ \\
\hline
\end{tabular}

The absence of reports to stakeholders related to risk analysis and risk profile

of the Integrated Service SIM
in Kotagede District, it is
recommended to make a
report to assess performance
related to the optimization of
existing risks. In order to be
given to stakeholders related
to risk analysis and profiles.

Based on the table 8 above, it is known that there are 3 gaps that must be met by the Integrated Service SIM in Kotagede District in order to fulfill the requirements to level 2 in the process APO12.

\section{CONCLUSION}

Based on the calculation results, the current Capability Level (as is) in the EDM03 Ensure Risk Optimization process is at level 2 (Managed Process) and the expected capability level (to be) is at level 3 (Established Process). Meanwhile, the current Capability Level (as is) in the APO12 Manage Risk process is at level 1 (Performed Process) and the expected capability level (to be) is at level 2 (Managed Process). The size of the gap formed between the current capability value and the expected capability value is 1 . This can be seen from the absence of a company entity that specifically supervises and has accountability for doing so. So that some recommendations are given to meet the next level.

\section{REFERENCES}

[1] Agtika, A. S., Mursityo, Y. T. and Rachmadi, A. (2019). Evaluation of Information Technology Risk Management at the Planning, Research and Development Agency (Barenlitbang) Malang City Using Cobit 5 Domain EDM03 and APO12. Journal of Information Technology Development and Computer Science, (5), pp. 4218-4225.

[2] Ali, Masyhud, 2006, Risk Management, Jakarta: PT Raja Grafindo Persada.

[3] Arief, M. H. and Suprapto (2018). Evaluation of Information Technology Risk Management Using the COBIT 5 Framework (Case Study at Perum Jasa Tirta I Malang). Journal of Information Technology and Computer Science Development, 2(1), pp. 101-109.

[4] Artikelsiana. Understanding Analysis, Objectives \& According to the Experts. Found on Saturday 10 April 2021, https://artikelsiana.com/pengertian-analisis-tujuananalisis/.

[5] Asari, S. O. (2020). Analysis of Risk Assessment in Corporate Postal Services Using the OCTAVE Allegro Framework. Information Systems Thesis, Ahmad Dahlan University, Yogyakarta, hlm. 17 - 19.

[6] Bungin, B. (2010). Quantitative Research Methods. Jakarta: Prenada Media gropu, Ed.

[7] Djojosoeharso, S. (1999). Principles of Risk Management and Insurance. Jakarta: Salemba Empat.

[8] Fahmi, I. (2012). Production and Operations Management. Bandung: Alfabeta.

[9] Ibrahim, B. (2009). Total Quality Management: A Guide to Facing Global Competition. Jakarta: PT. Gramedia Pustaka Utama. 
[10] ISACA. (2012). COBIT 5: A Business Framework for the Governance and Management of Enterprise IT. Rolling Meadows, ISACA.

[11] ISACA. (2012). COBIT 5 : A Business Framework For The Governance And Management Of Enterprise IT.

[12] Komaruddin, (2001). Ensilopedia Manajemen. Jakarta: Bumi Aksara

[13] Kotagede District, Yogyakarta. Main tasks of the district. Accessed on Wednesday 7 April 2020. https://kotagedekec.jogjakota.go.id.

[14] Kotagede District, Yogyakarta. Kotagede sub-district organizational structure. Accessed on Wednesday 7 April 2021,https://kotagedekec.jogjakota.go.id/page/index/stru ktur-organisasi.

[15] Khairuna, D., Wibowo, S. and Gamayanto, I. (2020). Evaluation of Information Technology Risk Management Using COBIT 5 Framework Based on Domain APO12 (Manage Risk) at the Head Office of BPR Agung Sejahtera. 5(1), pp. 18-26.

[16] Megawati and Syntia, A. (2018). Evaluation of Information Technology Risk Management Using the COBIT 5.0 Framework. Scientific Journal of Information
Systems Engineering and Management, 4(2), pp. 118 122.

[17] Putri, C. U. (2017). Risk Assessment of Information Technology Processes Based on the Cobit 5 Framework at the Helpdesk, Sub-directorate of Information Technology and Systems Services, Directorate of Information Technology and Systems Development (DPTSI) Sepuluh Nopember Institute of Technology. 241. http://repository.its.ac.id/3110/.

[18] Putri, Y. I., Suprapto and Herlambang, A. D. (2018). Assessment of the Application of Information Technology Risk Management Capability Using the COBIT 5 Framework (Study on PDAM Malang City, East Java). Journal of Information Technology and Computer Science Development, 2(11), pp. 4855-4862.

[19] Pendidik.co.id., 2021. Understanding Services According to Experts. Found on Wednesday 7 April 2021, from https://www.pendidik.co.id/pengertian-pelayanan.

[20] Stewart, J., Chapple, M., \& Gibson, D. (2015). CISSP(ISC) 2 Certified Information Systems Security Professional Official Study Guide. 7th Edition, Wiley.

[21] Yap, P. 2017. Corporate Risk Management. Jakarta: Growing Publishing. [16] 